\title{
Effects of $\mathrm{SO}_{2}$ oxidation on ambient aerosol growth in water and ethanol vapours
}

\author{
T. Petäjä ${ }^{1}$, V.-M. Kerminen ${ }^{2}$, K. Hämeri ${ }^{1}$, P. Vaattovaara ${ }^{3}$, J. Joutsensaari ${ }^{3}$, W. Junkermann ${ }^{4}$, A. Laaksonen ${ }^{3}$, and \\ M. Kulmala ${ }^{1}$ \\ ${ }^{1}$ Division of Atmospheric Sciences, Department of Physical Sciences, University of Helsinki, Finland \\ ${ }^{2}$ Climate and Global Change, Finnish Meteorological Institute, Finland \\ ${ }^{3}$ Department of Applied Physics, University of Kuopio, Finland \\ ${ }^{4}$ Institute for Meteorology and Climate Research, Forschungszentrum Karlsruhe, Germany
}

Received: 14 October 2004 - Published in Atmos. Chem. Phys. Discuss.: 26 November 2004

Revised: 14 February 2005 - Accepted: 22 February 2005 - Published: 10 March 2005

\begin{abstract}
Hygroscopicity (i.e. water vapour affinity) of atmospheric aerosol particles is one of the key factors in defining their impacts on climate. Condensation of sulphuric acid onto less hygroscopic particles is expected to increase their hygrocopicity and hence their cloud condensation nuclei formation potential. In this study, differences in the hygroscopic and ethanol uptake properties of ultrafine aerosol particles in the Arctic air masses with a different exposure to anthropogenic sulfur pollution were examined. The main discovery was that Aitken mode particles having been exposed to polluted air were more hygroscopic and less soluble to ethanol than after transport in clean air. This aging process was attributed to sulphur dioxide oxidation and subsequent condensation during the transport of these particle to our measurement site. The hygroscopicity of nucleation mode aerosol particles, on the other hand, was approximately the same in all the cases, being indicative of a relatively similar chemical composition despite the differences in air mass transport routes. These particles had also been produced closer to the observation site typically $3-8 \mathrm{~h}$ prior to sampling. Apparently, these particles did not have an opportunity to accumulate sulphuric acid on their way to the site, but instead their chemical composition (hygroscopicity and ethanol solubility) resembled that of particles produced in the local or semi-regional ambient conditions.
\end{abstract}

\section{Introduction}

Ambient aerosol particles influence the global climate directly by scattering and absorbing solar radiation and indirectly by acting as cloud condensation nuclei (CCN)

Correspondence to: T. Petäjä

(tuukka.petaja@helsinki.fi)
(Houghton et al., 2001). While the magnitude of both of these effects is highly uncertain, there are some indications that the indirect effect might dominate over the direct one in the global atmosphere (Lohman and Lesins, 2002; Sekiguchi et al., 2003). The ability of atmospheric aerosol particles to act as $\mathrm{CCN}$, and hence their potential indirect climatic effects, are dependent on their size and chemical composition. One of the key properties in this respect is the particle hygroscopicity, i.e. its affinity to water vapour (Covert et al., 1998; Roberts et al., 2002; Pradeep Kumar et al., 2003; Raymond and Pandis, 2003; Snider et al., 2003).

Atmospheric cloud condensation nuclei include primary particles emitted by various natural and anthropogenic sources, as well as secondary particles formed from gaseous precursors. Some primary particles act readily as CCN (Novakov and Corrigan, 1996; Ghan et al., 1998), while others, such as small soot particles originating from fossil fuel combustion, need to accumulate hygroscopic matter to convert them into good CCN. Formation of nanometer size secondary particles has been observed to take place all over the world (Kulmala et al., 2004). These particles, however, are not able to act as $\mathrm{CCN}$ before they have growth in size and become hygroscopic enough (Kerminen et al., 2000).

Measurements conducted in Hyytiälä, Finland by O'Dowd et al. (2002) demonstrated that newly-formed particles contain a large fraction of organic matter originating most probably from the surrounding boreal forests. The boreal forests emit volatile organic compounds (VOCs, eg. $\alpha$-pinene) which are oxidised in the atmosphere by $\mathrm{OH}$ (daytime), $\mathrm{NO}_{3}$ (nighttime) or $\mathrm{O}_{3}$ (both). A substantial part of the growth of newly-formed particles in Hyytiälä was attributed to the oxidation products of these organic compounds (Janson et al., 2001). Similarly, based on long term statistical analyses in a boreal forest, $8-50 \%$ of the observed growth rate of

(C) 2005 Author(s). This work is licensed under a Creative Commons License. 
nucleation mode $\left(\mathrm{D}_{p}<10 \mathrm{~nm}\right)$ particles could be explained by the condensation of certain organic vapours (Boy et al., 2003). However, the actual contribution may also be over $90 \%$. To characterize the growth of particles under the influence of water vapour, a hygroscopic growth factor (HGF) is used. It is determined as the ratio between the particle diameter at an elevated relative humidity versus its dry sample diameter. In laboratory experiments, the oxidation products of $\alpha$-pinene have been found to have a bulk hygroscopic growth factor (HGF) of about 1.1 at $85 \%$ relative humidity (Virkkula et al., 1999), and the oxidation products of toluene have been found to have a corresponding factor of 1.1-1.2 at $90 \%$ relative humidity (Petäjä et al., 2002). Some individual organic compounds identified in atmospheric particle samples have, however, hygroscopic growth factors comparable to those of common inorganic salts, (e.g. HGF of 1.80 and 1.85 for sodium methyl sulfonic acid and sodium succinate, respectively, according to Peng et al., 2001).

Condensation of gaseous sulphuric acid increases significantly the water affinity of originally less hygroscopic particles, such as fresh combustion particles or secondary particles consisting predominantly of organic compounds. As a result, the CCN activity of particles affected by high sulphur dioxide mixing ratios during atmospheric transport is expected to increase. Little observational evidence of this kind of an aging process for ambient particles has been obtained, especially regarding particles in the Aitken and nucleation mode size ranges.

The focus of this study was to examine differences in the hygroscopic properties of aerosol particles in Arctic air masses observed with a Hygroscopic Tandem Differential Mobility Analyser (HTDMA). In addition, variations in the ethanol uptake of these particles were monitored with an Organic Tandem Differential Mobility Analyser (OTDMA). These complementary systems can give an indication of the differences and similarities of gas phase uptake properties of the sampled aerosol particles and of their dependency on the air mass histories. For this purpose, particle formation event days with air of different magnitude and timing of exposure to anthropogenic sulphur dioxide concentrations were selected. Condensation of sulphuric acid onto larger Aitken particles and subsequent enchancement in their hygroscopicity was observed for cases having a longer time for sulphur dioxide oxidation. The dependence of hygroscopic properties and ethanol uptake of nucleation mode particles during new-particle formation events with different air mass histories was also examined.

\section{Experimental Setup}

\subsection{Site description}

The measurements were conducted as a part of "Quantification of Aerosol Nucleation in the European Boundary Layer"
(QUEST) intensive field campaign in the SMEAR II (Station for Measuring Forest Ecosystem-Atmosphere Relations) field station in Hyytiälä during March-April, 2003. The SMEAR II site is located in the Southern Finland $\left(61^{\circ} 51^{\prime} \mathrm{N}\right.$, $24^{\circ} 17^{\prime} \mathrm{E}, 181 \mathrm{~m}$ a.s.l.), which is surrounded by a 40 -year-old pine forest (Pinus Sylvestris $L$.). A detailed description of the station and the instrumentation within can be found elsewhere (e.g. Vesala et al., 1998; Kulmala et al., 2001b; Aalto et al., 2001).

\subsection{Aerosol and trace gas measurements}

Aerosol size distributions were measured with a Differential Mobility Particle Sizer (DMPS). The system, described by Aalto et al. (2001), can measure particles from $3 \mathrm{~nm}$ to about $600 \mathrm{~nm}$ in diameter in 10-min time resolution. The aerosol size distribution was used to determine the starting time of the nucleation events as well as to characterize aerosol number concentrations during a course of nucleation event days.

Chemical analysis of nucleation mode particles $\left(\mathrm{D}_{p}<20 \mathrm{~nm}\right)$ is extremely difficult. Excluding the recent study by Smith et al. (2004), information about the chemical composition of these particles can be obtained only via indirect methods. Indirect methods do not always enable a quantitative analysis of the chemistry but allow one to characterize certain key elements based on on their behaviour and changing thermodynamic conditions. To study the effects of chemical aging of aerosols on their ability to accumulate water and to act as $\mathrm{CCN}$, the chemical composition is not a basic requirement. The physical behaviour might be sufficient to describe the aerosol and to get an estimate of the chemical composition. For example, observation of water absorption into aerosol phase in sub-saturated conditions with a Hygroscopic Tandem Differential Mobility Analyser (HTDMA) (McMurry and Stolzenburg, 1989; Hämeri et al., 2000) can be utilized to tentatively identify the particle composition, since water accumulation is specifically dependent on the chemical composition. The idea in the TDMA method, in short, is that a monodisperse aerosol sample is first separated from the ambient aerosol with a Differential Mobility Analyzer (DMA, Winklmayr et al. (1991)), and then treated with a controlled amount of water vapour. At high relative humidities, soluble compounds in the aerosol sample take up water vapour into the aerosol phase until an equilibrium size is reached. This size change is monitored with the second DMA that is scanned through classifying voltages. Then a Condensation Particle Counter (CPC 3010, TSI Inc., USA) is used to measure particle concentrations in each size bin. As a result, a hygroscopic growth factor (HGF) can be derived. The HGF is defined as the ratio between the particle diameter at an elevated relative humidity versus its dry sample diameter.

In order to gain more information on the chemical composition of the particles, also particle growth factors in ethanol 
vapour were measured using an Organic Tandem Differential Mobility Analyzer (OTDMA) (Joutsensaari et al., 2001). This device is similar to the HTDMA, but instead of water vapour, the particles are treated in ethanol vapour with saturation ratios of $0.82 \pm 0.02$. Many organic species take up ethanol vapour causing the particles to growth, whereas many inorganic species (e.g. ammonium sulphate) do not. Thus, information complementary to the HTDMA measurements is obtained. This can give an estimation of the main constituents of the aerosol particles. As a summary, hygroscopicity and ethanol solubility of several types of atmospheric aerosol particles are presented in Table 1.

In this study, the hygroscopic growth factors of 10, 20 and $50 \mathrm{~nm}$ particles were studied using a HTDMA system identical to the system described by Hämeri et al. (2000). Each dry size was scanned every $10 \mathrm{~min}$. The relative humidity inside the second DMA was monitored with Vaisala HMM-211 dew point sensors $( \pm 2 \% \mathrm{RH}$ at $0-100 \%)$ within sheath and excess flows. A Hygro M4 dew point monitor with chilled mirror sensor (D-2) operating in the excess flow of the DMA 2 was used as an internal reference for the relative humidity $( \pm 1.25 \% \mathrm{RH}$ at $95 \%)$. Also OTDMA revealed growth factors for 10, 20 and $50 \mathrm{~nm}$ particles in approximately 10-min time resolution for each dry size. Ethanol saturation ratio inside the system was monitored with A Hygro M4 dew point monitor with chilled mirror sensor (D-2).

The functionality of the HTDMA system was verified daily by measuring the hygroscopic growth factor of ammonium sulphate particles generated with a TSI 3076 Constant Output Atomizer at $90 \%$ relative humidity. Occasionally dry calibrations were conducted, in which the growth factor of pure ammonium sulphate was measured at $<2 \% \mathrm{RH}$. This correction was less than $3 \%$ for all the sizes, which indicates that the classifying voltages inside the DMAs were set correctly.

The hygroscopic growth factors were inverted from the raw data taking into account diffusion broadening due to Brownian diffusion inside the DMAs (Stolzenburg, 1988). Due to small sizes of initial dry particles $(50 \mathrm{~nm}$ in diameter or less), multiple charging was neglected. Furthermore, both diffusion losses inside sampling lines and deterioration of the detection efficiency of TSI 3010 particle counter were neglected in the data analysis. In the OTDMA data analysis, diffusion broadening of the kernels were not taken into account.

Log-normal curves were fitted in a least squares sense to the inverted growth spectra. Geometric mean values of only the most dominant (i.e. largest hygroscopic mode numberwise) were calculated. External mixing of aerosols was left out of further analysis. Growth spectra in ethanol vapour were dominantly unimodal, whereas external mixing was frequently observed with the HTDMA especially in the $50 \mathrm{~nm}$ particle size.

Sulphur dioxide was measured with a fluorescence analyser (Model 43S, Thermo Environmental Instruments Inc.,
Table 1. Differences in the water and ethanol solubilities of several categories of ambient aerosol particles (adapted from Joutsensaari et al. 2001). HTDMA and OTDMA refers to Hygroscopic and Organic Tandem Differential Mobility Analyzers, respectively.

\begin{tabular}{lcc}
\hline Category & HTDMA & OTDMA \\
\hline $\begin{array}{l}\text { inorganic salt } \\
\text { (e.g. ammonium sulphate) }\end{array}$ & soluble & insoluble \\
sulphuric acid & soluble & soluble \\
$\begin{array}{l}\text { water-soluble organics } \\
\text { (e.g. oxidation producs of alpha-pinene) }\end{array}$ & soluble & soluble \\
$\begin{array}{l}\text { water-insoluble organics } \\
\text { (e.g. adipic acid) }\end{array}$ & insoluble & soluble \\
crustal material & & \\
and elemental carbon & insoluble & insoluble \\
\hline
\end{tabular}

detection limit $0.1 \mathrm{ppb})$. The ozone concentration was monitored with an ultraviolet light absorption analyser (TEI 49, Thermo Environmental Instruments, Franklin, MA, USA, detection limit $1 \mathrm{ppb}$ ) and $\mathrm{NO}_{\mathrm{x}}$ with a chemiluminescence analyser (TEI 42C TL, Thermo Environmental Instruments, Franklin, MA, USA, detection limit $0.1 \mathrm{ppb}$ ). Gas phase concentrations were measured from a 70-m-tall mast from different heights. For a characteristic value for the air masses, mean values of 30 -min averages at $16.8-\mathrm{m}$ height were used in the study.

\subsection{Ancillary data}

The concentration of water vapour in the ambient air measured with an infrared light absorption analyser (URAS 4 $\mathrm{H}_{2} \mathrm{O}$, Hartmann \& Braun, Frankfurt am Main). The relative humidity was then calculated from measured water vapour concentrations and temperature measurements (Pt100). Ambient temperature sensors were ventilated and protected from direct solar radiation. Wind velocity was measured with a cup anemometer (A101M/L, Vector Instruments, Rhyl, Clwyd, UK) (threshold $0.15 \mathrm{~m} / \mathrm{s}$ ) and wind direction at $16 \mathrm{~m}$ height with a wind vane (W200P, Vector Instruments, Rhyl, Clwyd, UK) above the tree-top level (threshold $0.6 \mathrm{~m} / \mathrm{s}$ ).

Backtrajectories of air mass during QUEST Hyytiälä campaign were calculated with the HYSPLIT model (Draxler and Rolph (2003); Rolph (2003)). According to these trajectories, three selected case studies were chosen for a more closer examination.

\section{Results}

\subsection{Nucleation events in the SMEAR II station}

During the QUEST project field campaign in March-April, 2003, in Hyytiälä, more than 20 particle formation events 


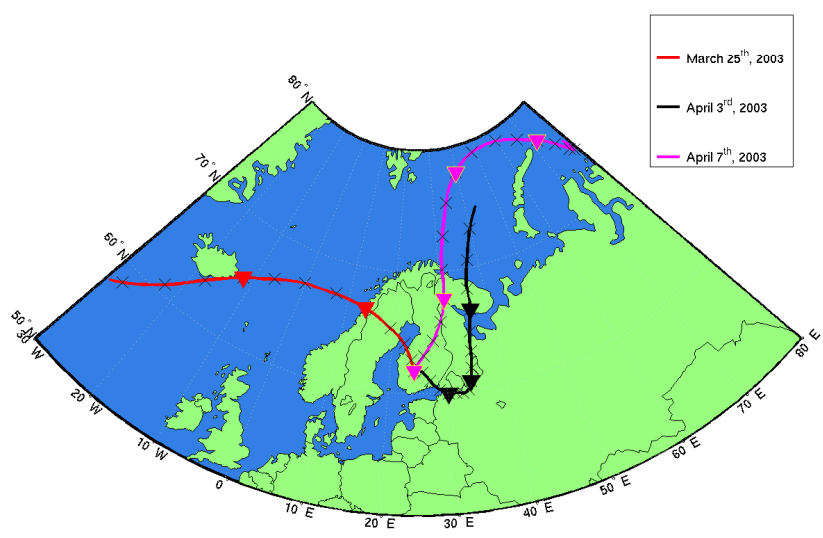

Fig. 1. HYSPLIT backward trajectories arriving to Hyytiälä site at 10 UTC during selected days. During 25 March 2003 air parcels arrived to the Hyytiälä site without any major contact with anthropogenic sources of $\mathrm{SO}_{2}$ (Case 1). The route is identified with a red line. On 3 April 2003 the Arctic air circumvented Kola Peninsula industrial regions from the east and passed over the St. Petersburg region and the Estonian heavy industry in Narva before entering the measurement site (Case 2, indicated with a black line). On 7 April 2003 initially clean Arctic air passed over the source area of gaseous sulphur dioxide pollution in the Kola region approximately $30 \mathrm{~h}$ prior sampling in Hyytiälä (Case 3, indicated with a magenta line). Starting height for all the trajectory calculatios was $180 \mathrm{~m}$ above ground level. Crosses and closed triangles are 6 and $24 \mathrm{~h}$ time marks, respectively.

were observed. The production of nucleation mode particles was in accordance with the conclusions by Nilsson et al. (2001a) in the way that a high nucleation probability was associated with cold air advection or cold air outbreaks behind cold fronts. In previous studies, bursts of new nuclei have been also been linked to the boundary layer development (Nilsson et al., 2001b; Buzorius et al., 2003) as well as to a low condensation (and coagulation) sink for nucleating vapours and fresh nuclei (Kulmala et al., 2001a; Kulmala, 2003).

\subsection{Selected case studies}

Most of the particle formation events during the QUEST measurement campaign took place in cold and originally very clean air coming from the Arctic Ocean or Northern Atlantic. However, there were differences in the levels of anthropogenic pollution, particularly in the $\mathrm{SO}_{2}$ concentration, that these air masses encountered prior to their arrival to Hyytiälä. In this respect, the observed events were divided into three different categories: 1) air without any major contact with anthropogenic sources of $\mathrm{SO}_{2}, 2$ ) air passing over the St. Petersburg region and/or the heavy Estonian industry in Narva prior to entering the measurement site, and 3) air that had been affected by $\mathrm{SO}_{2}$ emitted from smelters and ore refineries in the Kola Peninsula area. One case correspond- ing to each of the backtrajectory categories was selected for a closer examination (Fig. 1). Due to the shortness of the intensive measurement campaign in Hyytiälä and strict requirements of backward trajectories, only a limited number of days were eligible for this study, for polluted Arctic air masses in particular. Clean Arctic (Case 1) type air mass, however, was regularly observed during the QUEST measurement campaign. These days resembled the selected day (25 March 2003) in terms of hygroscopicity, ethanol uptake and gaseous pollutant levels.

The selected three cases were further divided into three time periods: that before, that during and that after the observed nucleation event. For each case and all time periods, the averages of the total particle number concentration, trace gas concentrations $\left(\mathrm{SO}_{2}, \mathrm{NO}_{\mathrm{x}}\right.$, ozone) and meteorological parameters (ambient temperature and and relative humidity, wind direction and velocity) were calculated (Table 2). Important parameters describing the functionality of the both TDMA systems were also reported, along with the mean growth factors of 10,20 and $50 \mathrm{~nm}$ particles in both water and ethanol vapours.

The hygroscopic growth factors of $50 \mathrm{~nm}$ particles reveal the water uptake properties of the "background aerosol" in sampled air masses. Furthermore, this size is close to the lowest observed cloud droplet activation diameter in clean air masses, putting its hygroscopic properties in a key position. Combined with observed ethanol uptake, this gives a tentative indication of possible composition of these transported aerosol particles. The growth factors of 10 and $20 \mathrm{~nm}$ particles, on the other hand, provide information about the hygroscopic properties of particles formed recently in the atmosphere by nucleation.

\subsubsection{Case 1, 25 March 2003}

According to HYSPLIT-backtrajectories, the origin of the measured air mass during 25 March 2003 was the Norwegian Sea and Iceland (Fig. 1). Gaseous pollutant levels stayed low during the whole day $\left(\mathrm{SO}_{2}<0.2 \mathrm{ppb}, \mathrm{NO}_{\mathrm{x}}<1 \mathrm{ppb}\right.$, Table 2).

The aerosol number size distribution was dominated by the Aitken mode during the night. These particles can be interpreted as a result of a nucleation event a day before. Over the course of the night, the mode grew in size up to $50 \mathrm{~nm}$ and at the same time the observed hygroscopic growth factor of $50 \mathrm{~nm}$ particles decreased (Fig. 2). A minimum in the water uptake was observed at 06:00 (LT) $(\mathrm{HGF}=1.06)$, approximately three hours prior to the onset of the nucleation event. This is quite a typical diurnal feature detected earlier by Hämeri et al. (2001) in Hyytiälä. One possible explanation for the minimum in HGF is an enchanced source rate of organic vapours of rather low solubility and their subsequent condensation during night-time (Janson et al., 2001). Most of the oxidation products of $\alpha$-pinene have seen to be only slightly hygroscopic in laboratory experiments (Virkkula et al., 1999). Since the measured air mass 
Table 2. Characteristic averages for different air masses before, during, and after selected nucleation event days. EGF denotes the growth factors in ethanol vapour and HGF, in turn, indicate the observed growth of particles in water vapour. Standard deviations of mean quantities are in parentheses. The second value in the parenthesis after mean growth factors indicates the number of observations. Missing data is marked with n.a. (not available).

\begin{tabular}{|c|c|c|c|}
\hline & Clean Arctic & Arctic and Estonia & Arctic and Kola \\
\hline \multicolumn{4}{|c|}{ Before nucleation burst (0-9 a.m.) } \\
\hline Aerosol concentration $\left[\mathrm{cm}^{-3}\right]$ & $3400(600)$ & $5900(800)$ & $1700(600)$ \\
\hline Temperature $\left[{ }^{\circ} \mathrm{C}\right]$ & $-0.2(0.7)$ & $-5.7(0.5)$ & $-7.2(1.4)$ \\
\hline Relative humidity [\%] & $90(4)$ & $66(3)$ & $92(9)$ \\
\hline Wind velocity $\left[\mathrm{m} \mathrm{s}^{-1}\right]$ & $2.0(0.3)$ & $2.0(0.4)$ & $2.7(0.5)$ \\
\hline Wind direction $\left[{ }^{\circ}\right]$ & $303(20)$ & $102(20)$ & $25(11)$ \\
\hline $\mathrm{SO}_{2}$ conc. $[\mathrm{ppb}]$ & $0.2(0.2)$ & $1.4(0.6)$ & $0.4(0.3)$ \\
\hline $\mathrm{O}_{3}$ conc. $[\mathrm{ppb}]$ & $38(1.2)$ & $36(2)$ & $27(1.0)$ \\
\hline $\mathrm{NO}_{\mathrm{x}}$ conc. $[\mathrm{ppb}]$ & $0.96(0.13)$ & $2.8(0.8)$ & $0.9(0.4)$ \\
\hline $\mathrm{S}$ in OTDMA [\%] & $82.2(0.9)$ & $83.8(0.3)$ & $83.0(0.3)$ \\
\hline $\mathrm{T}$ in OTDMA $\left[{ }^{\circ} \mathrm{C}\right]$ & $24.8(0.02)$ & $24.9(0.01)$ & $24.9(0.03)$ \\
\hline EGF $(50 \mathrm{~nm})$ & $1.14(0.01)(11)$ & $1.10(0.01)(13)$ & $1.10(0.02)(10)$ \\
\hline EGF (20 nm) & $1.12(0.03)(6)$ & $1.10(0.01)(13)$ & $1.11(0.01)(10)$ \\
\hline EGF (10 nm) & n. a. & 1.08 (n.a) (1) & n.a. \\
\hline RH in HTDMA [\%] & $89.46(0.02)$ & $89.42(0.04)$ & $89.38(0.03)$ \\
\hline $\mathrm{T}$ in HTDMA $\left[{ }^{\circ} \mathrm{C}\right]$ & $24.40(0.01)$ & $24.60(0.01)$ & $23.20(0.03)$ \\
\hline HGF $(50 \mathrm{~nm})$ & $1.09(0.03)(17)$ & $1.23(0.03)(17)$ & $1.44(0.15)(16)$ \\
\hline $\mathrm{HGF}(20 \mathrm{~nm})$ & $1.09(0.11)(17)$ & $1.20(0.04)(17)$ & $1.24(0.06)(15)$ \\
\hline HGF (10 nm) & $1.14(0.11)(14)$ & $1.15(0.08)(17)$ & $1.21(0.07)(16)$ \\
\hline \multicolumn{4}{|c|}{ During nucleation burst (9-12 a.m.) } \\
\hline Aerosol concentration $\left[\mathrm{cm}^{-3}\right]$ & $4000(1200)$ & $13000(4000)$ & $7000(4000)$ \\
\hline Temperature $\left[{ }^{\circ} \mathrm{C}\right]$ & $3.6(1.1)$ & $-2(2)$ & $-2.8(0.8)$ \\
\hline Relative humidity [\%] & $59(10)$ & $50(7)$ & $51(6)$ \\
\hline Wind velocity $\left[\mathrm{m} \mathrm{s}^{-1}\right]$ & $2.7(0.6)$ & $1.8(0.4)$ & $4.5(0.6)$ \\
\hline Wind direction $\left[{ }^{\circ}\right]$ & $347(8)$ & $71(12)$ & $39(5)$ \\
\hline $\mathrm{SO}_{2}$ conc. $[\mathrm{ppb}]$ & $0.15(0.15)$ & $3.2(1.3)$ & $0.4(0.2)$ \\
\hline $\mathrm{O}_{3}$ conc. $[\mathrm{ppb}]$ & $41(1.1)$ & $37(2)$ & $35(1.2)$ \\
\hline $\mathrm{NO}_{\mathrm{x}}$ conc. $[\mathrm{ppb}]$ & $0.78(0.14)$ & $3.2(0.7)$ & $0.75(0.14)$ \\
\hline $\mathrm{S}$ in OTDMA [\%] & $82.3(0.5)$ & $83.9(0.2)$ & $82.7(0.4)$ \\
\hline $\mathrm{T}$ in OTDMA $\left[{ }^{\circ} \mathrm{C}\right]$ & $24.8(0.03)$ & $24.9(0.01)$ & $25.0(0.02)$ \\
\hline EGF $(50 \mathrm{~nm})$ & $1.17(0.02)(4)$ & $1.12(0.01)(5)$ & $1.13(0.04)(3)$ \\
\hline EGF $(20 \mathrm{~nm})$ & $1.16(0.01)(3)$ & $1.11(0.01)(5)$ & $1.13(0.01)(3)$ \\
\hline EGF (10 nm) & 1.08 (n.a.) (1) & $1.07(0.01)(4)$ & $1.06(0.04)(3)$ \\
\hline RH in HTDMA [\%] & $89.2(0.01)$ & $89.3(0.01)$ & $89.5(0.01)$ \\
\hline $\mathrm{T}$ in HTDMA $\left[{ }^{\circ} \mathrm{C}\right]$ & $24.5(0.01)$ & $24.7(0.01)$ & $24.2(0.02)$ \\
\hline HGF (50 nm) & $1.10(0.01)(2)$ & $1.30(0.03)(5)$ & $1.73(0.05)(6)$ \\
\hline HGF $(20 \mathrm{~nm})$ & $1.15(0.01)(2)$ & $1.33(0.04)(5)$ & $1.42(0.06)(6)$ \\
\hline HGF (10 nm) & $1.19(0.03)(3)$ & $1.33(0.03)(5)$ & $1.28(0.06)(4)$ \\
\hline \multicolumn{4}{|c|}{ After nucleation burst (12 a.m.-12 p.m.) } \\
\hline Aerosol concentration $\left[\mathrm{cm}^{-3}\right]$ & $6900(2000)$ & $6600(3300)$ & $7100(3700)$ \\
\hline Temperature $\left[{ }^{\circ} \mathrm{C}\right]$ & $5(2)$ & $-0.4(1.2)$ & $-3(2)$ \\
\hline Relative humidity [\%] & $42(7)$ & $51(20)$ & $49(10)$ \\
\hline Wind velocity $\left[\mathrm{m} \mathrm{s}^{-1}\right]$ & $1.8(0.8)$ & $2.5(0.6)$ & $3.6(1.0)$ \\
\hline Wind direction $\left[{ }^{\circ}\right]$ & $87(130)$ & $6(40)$ & $37(8)$ \\
\hline $\mathrm{SO}_{2}$ conc. $[\mathrm{ppb}]$ & $0.17(0.14)$ & $0.6(0.3)$ & $0.4(0.3)$ \\
\hline $\mathrm{O}_{3}$ conc. $[\mathrm{ppb}]$ & $44(2)$ & $41(3)$ & $39(2)$ \\
\hline $\mathrm{NO}_{\mathrm{x}}$ conc. $[\mathrm{ppb}]$ & $1.0(0.6)$ & $1.7(0.3)$ & $0.7(0.2)$ \\
\hline $\mathrm{S}$ in OTDMA [\%] & $81.9(0.8)$ & $83.9(0.2)$ & $82.9(0.4)$ \\
\hline $\mathrm{T}$ in OTDMA $\left[{ }^{\circ} \mathrm{C}\right]$ & $24.8(0.07)$ & $24.9(0.02)$ & $25.0(0.01)$ \\
\hline EGF $(50 \mathrm{~nm})$ & $1.18(0.02)(9)$ & $1.12(0.01)(15)$ & $1.14(0.02)(11)$ \\
\hline EGF (20 nm) & $1.15(0.02)(10)$ & $1.11(0.02)(14)$ & $1.11(0.02)(12)$ \\
\hline EGF $(10 \mathrm{~nm})$ & $1.12(0.02)(7)$ & $1.10(0.01)(13)$ & $1.08(0.01)(13)$ \\
\hline RH in HTDMA [\%] & $89.4(0.06)$ & $89.4(0.02)$ & $89.2(0.2)$ \\
\hline $\mathrm{T}$ in HTDMA $\left[{ }^{\circ} \mathrm{C}\right]$ & $24.4(0.01)$ & $24.8(0.02)$ & $24.9(0.01)$ \\
\hline $\operatorname{HGF}(50 \mathrm{~nm})$ & $1.21(0.06)(20)$ & $1.32(0.04)(19)$ & $1.42(0.15)(19)$ \\
\hline $\mathrm{HGF}(20 \mathrm{~nm})$ & $1.18(0.06)(20)$ & $1.28(0.03)(20)$ & 1.25 (0.09) (19) \\
\hline HGF (10 nm) & $1.17(0.05)(16)$ & $1.26(0.06)(18)$ & 1.27 (0.06) (19) \\
\hline
\end{tabular}



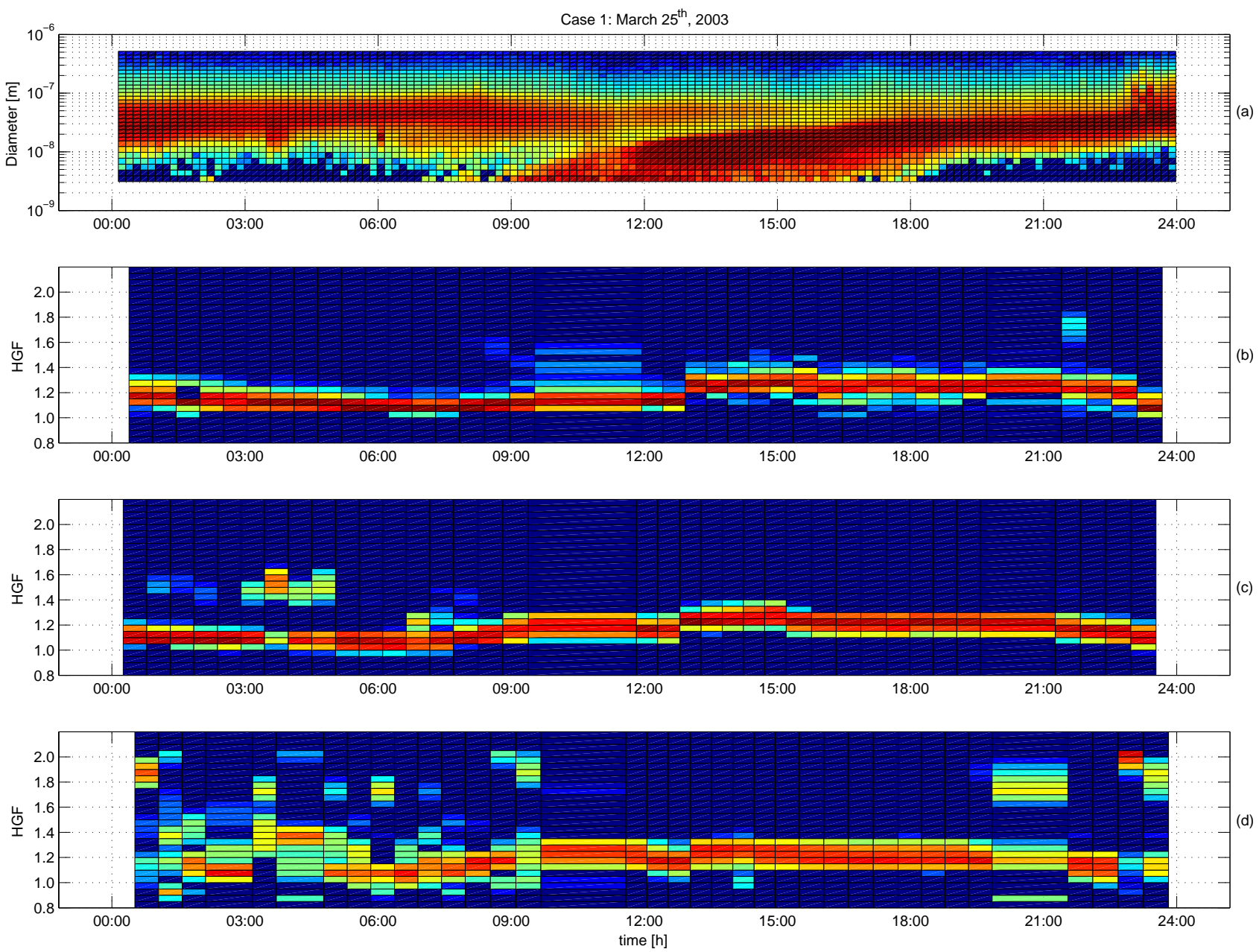

Fig. 2. Aerosol number size distribution during 25 March 2003 (Case 1) in Hyytiälä as a contour plot (a). Nucleation burst occured at 9 (LT). Hygroscopic growth factors of $50 \mathrm{~nm}(\mathbf{b}), 20 \mathrm{~nm}$ (c) and $10 \mathrm{~nm}$ (d) particles measured with HTDMA at $90 \%$ relative humidity is presented in contour plots. Colors represent the relative contribution of a certain growth factor to the total measured spectra. The hygroscopicity of all sizes remained unimodal throught the day i.e. the particles were internally mixed with respect to their affinity to water vapour. A slight increase in the water uptake was observed after nucleation burst in all the sizes. Note a measurement break due to malfunction of the HTDMA system between 10 a.m. and 12 a.m. Scatter in the measured growth factors prior to the nucleation event is a result of low concentration of ultrafine particles before the nucleation burst.

had not been in direct contact with any major anthropogenic sulphur dioxide source areas, it is likely that the $50 \mathrm{~nm}$ particles had accumulated only minor amounts of sulphuric acid along their way to the measurement site.

Growth factors in ethanol (EGF) showed a relatively constant value of about 1.14 throughout the night (Fig. 3). Laboratory measurements (Joutsensaari et al., 2004) have shown that the EGF of $100 \mathrm{~nm}$ ammonium bisulphate particles is close to this value; however, the HGF measurements clearly rule out high sulphate contents. The EGFs for substances that grow well in ethanol vapour at saturation ratios around 0.83 (e.g. citric acid, tartaric acid) are on the order of 1.4-1.5. Thus, the growth factor of 1.14 can either signify compounds that show moderate affinity to ethanol, or internal mixtures of ethanol insoluble (e.g. ammonium sulphate and soot) and well soluble compounds.

At 09:00 (LT), nucleation produced new particles and the observed particle number concentration increased by about a factor of three over the next six hours. Throughout the day, the hygroscopicity of particles increased slightly in all sizes. Unfortunately there was a gap of $2.5 \mathrm{~h}$ in the HTDMA data in the beginning of the nucleation event. A subsequent decrease towards the midnight in the water uptake was observed in all sizes. The measured growth factor maximum for the Aitken mode particles $(50 \mathrm{~nm})$ was 1.25 while the midnight minimum was 1.1. Correspondingly, the EGF increased to 1.2 at around 12:00 (LT), and decreased after that toward the evening. Interestingly, at around 22:30 (LT), the particle 

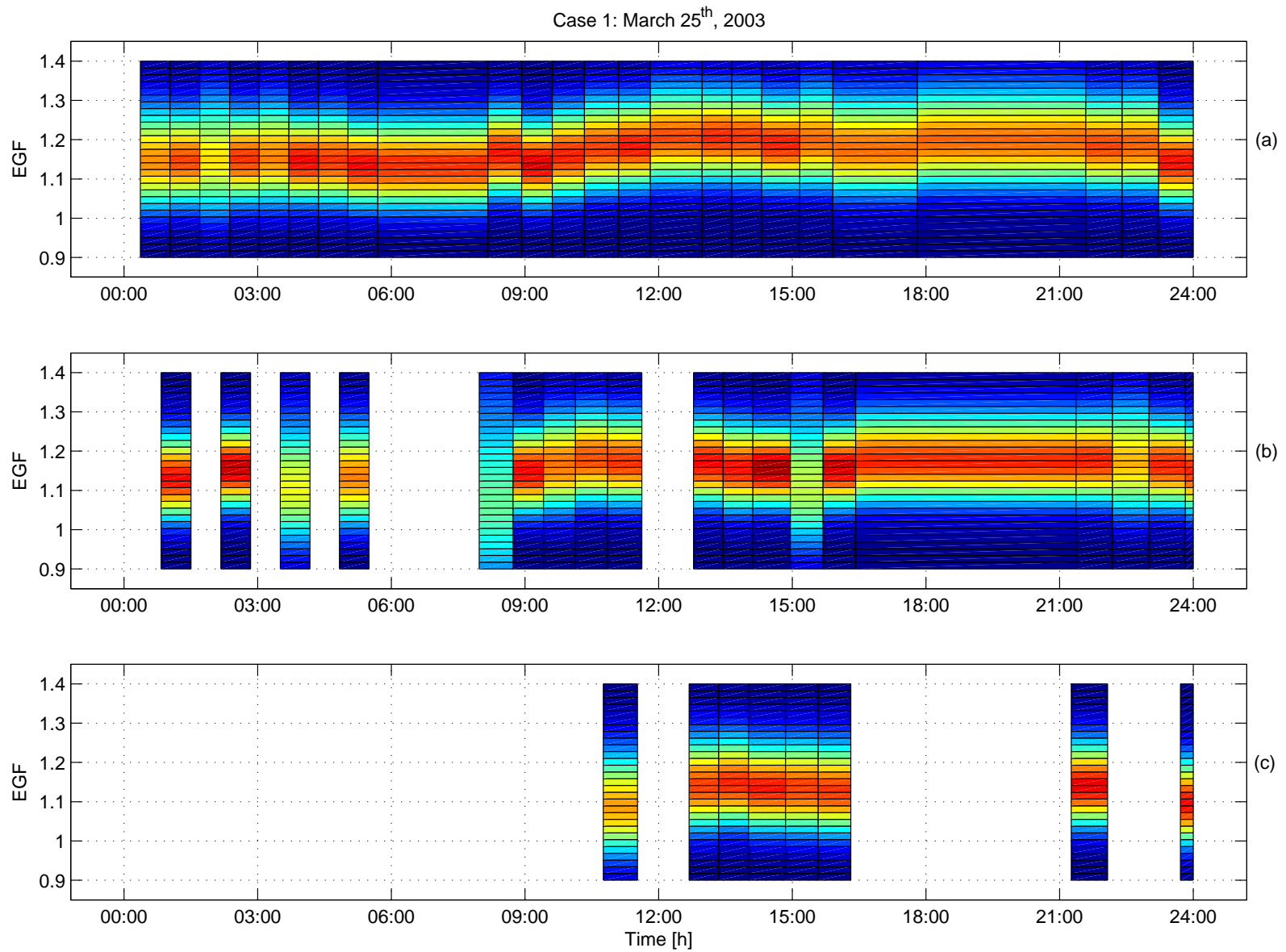

Fig. 3. Observed growth factors in ethanol vapour during 25 March 2003 (Case 1) in Hyytiälä for $50 \mathrm{~nm}$ (a), $20 \mathrm{~nm}$ (b) and $10 \mathrm{~nm}$ initially dry particles. An increase in the ethanol uptake is observed in daylight hours.

concentrations increased rapidly (Fig. 2), which appears as a sudden jump in the growth of the nucleated particles. At the same time, both growth factors dropped (HGF: 1.2 to 1.1, EGF: 1.18 to 1.13 , Figs. 2 and 3). Examination of backtrajectories reveals that the even though the air arriving at Hyytiälä still had the same origin as before, it had made a loop south of Hyytiälä. Also, the local wind direction changed from 360 degrees at 18:00 (LT) to 180 degrees at 23:00 (LT). We interpret the increase in the Aitken mode concentrations as pollution particles originating possibly from the Tampere city area. The fact that both growth factors dropped may indicate that the particles contained a relatively large fraction of soot.

During the day, the $10 \mathrm{~nm}$ particle growth factors behaved in much the same way as the $50 \mathrm{~nm}$ GFs. Thus the maximum and minimum HGF's were 1.22 and 1.08, and the maximum and minimum EGF's 1.19 and 1.08, respectively.

In summary, the hygroscopic and ethanol GFs increased during the daytime, suggesting the presence of condensable vapours with a higher affinity to both water and ethanol vapours than that the compounds already present in the particulate phase had. Furthermore, the particle hygroscopicity decreased towards the evening, indicating the condensation of some less hygroscopic compound later during the day. The ethanol growth factor started decreasing already earlier. Also heterogenous reactions inside and on the surface of the particles could alter the water and ethanol uptake of ambient aerosol particles, and they cannot be ruled out by these measurements. Just before midnight, the wind direction turned to south, accompanied by an increase in Aitken mode concentrations and decreases in the values of both growth factors, possibly indicating that the increased concentrations were caused by pollution particles containing soot.

\subsubsection{Case 2, 3 April 2003}

During 3 April 2003, an Arctic air mass originating from the Arctic Ocean passed over the Kola Peninsula industrial region from the east and made a southerly loop over Saint Petersburgh in Russia and Narva (Estonian industrial area) (Fig. 1). Gas phase pollutant concentrations were 3-21 $\left(\mathrm{SO}_{2}\right)$ and 2-4 $\left(\mathrm{NO}_{\mathrm{x}}\right)$ times higher during this day than in $25 \mathrm{March}$ 2003. This is a clear indication of the interaction of the measured air masses with anthropogenic sources. The transport 

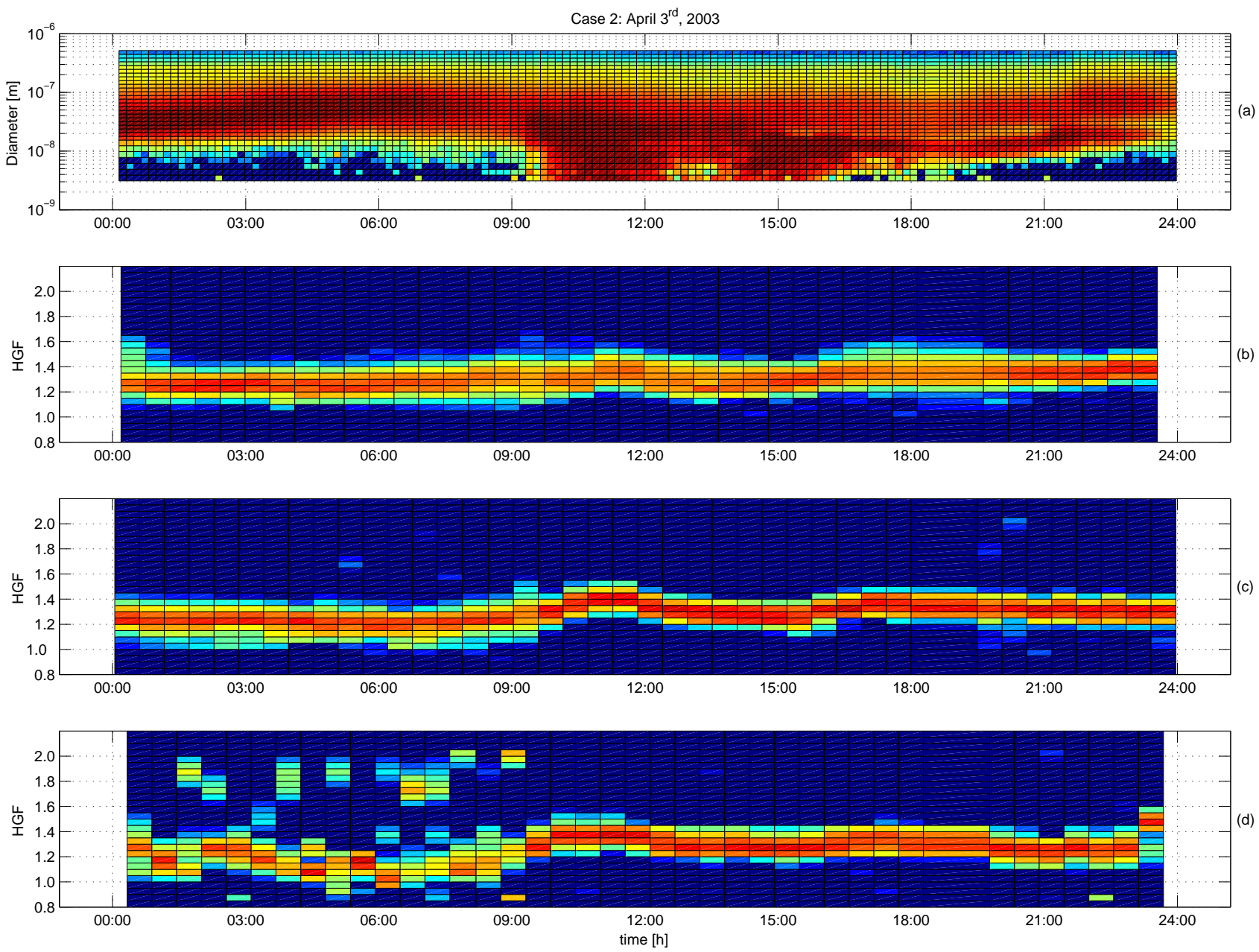

Fig. 4. Aerosol number size distribution during 3 April 2003 (Case 2) in Hyytiälä as a contour plot (a). Nucleation burst occured at 9 (LT). Hygroscopic growth factors of $50 \mathrm{~nm}(\mathbf{b}), 20 \mathrm{~nm}(\mathbf{c})$ and $10 \mathrm{~nm}(\mathbf{d})$ particles measured with HTDMA at $90 \%$ relative humidity are presented in contour plots. Colors represents the relative contribution of a certain growth factor to the total measured spectra. Minimum water uptake occured approximately $3 \mathrm{~h}$ before the nucleation event for all sizes, but was more prominent in the smaller sizes. The maximum was, in turn, observed during the nuclation burst.

of air from Estonia to Hyytiälä took approximately $24 \mathrm{~h}$, which was not enough for a complete oxidation of sulphur dioxide into gaseous sulphuric acid.

The total particle number concentration before the nucleation event was of a same order of magnitude as in Case 1 after the burst of new particles. Despite the larger condensation sink in this case, new-particle formation was observed in Hyytiälä (Fig. 4).

The hygroscopicity of the background aerosol $(50 \mathrm{~nm})$ was higher during 3 April 2003 than in Case 1 throughout the day. This suggests that these particles had a larger sulphate fraction, most likely as a result of condensation from the gas phase during atmospheric transportation (aerosol aging). The water uptake of the background aerosol increased during the morning with a maximum at 11:00 $(\mathrm{HGF}=1.32)$, followed by a minimum at at 13:00 $(\mathrm{HGF}=1.20)$. In the afternoon hygro- scopicity increased again and by midnight a growth factor of 1.38 was reached (Fig. 4). In contrast, growth factors in ethanol (Fig. 5) were lower compared to case 1 indicating higher inorganic or soot fraction in the particles. The mean EGF of $50 \mathrm{~nm}$ particles had a more or less constant value of 1.1 throughout the night, increased to a maximum of 1.18 at 14:00 (LT), and decreased back to 1.1 by $22: 00$ (LT).

The diurnal variation of the hygroscopicity of $10 \mathrm{~nm}$ particles resembled that of the background particles, even though the maximum was reached slightly earlier (10:00 (LT), HGF=1.35). Towards the evening measured growth factors approached the value of 1.2 which is equal to that of $20 \mathrm{~nm}$ particles in Case 1. Therefore, the water soluble fraction was higher during this day. The maximum EGF for 10 $\mathrm{nm}$ particles was 1.12 at around 20:00 (LT), i.e. lower than in Case 1 (1.14). This also suggests a slightly higher sulphate 

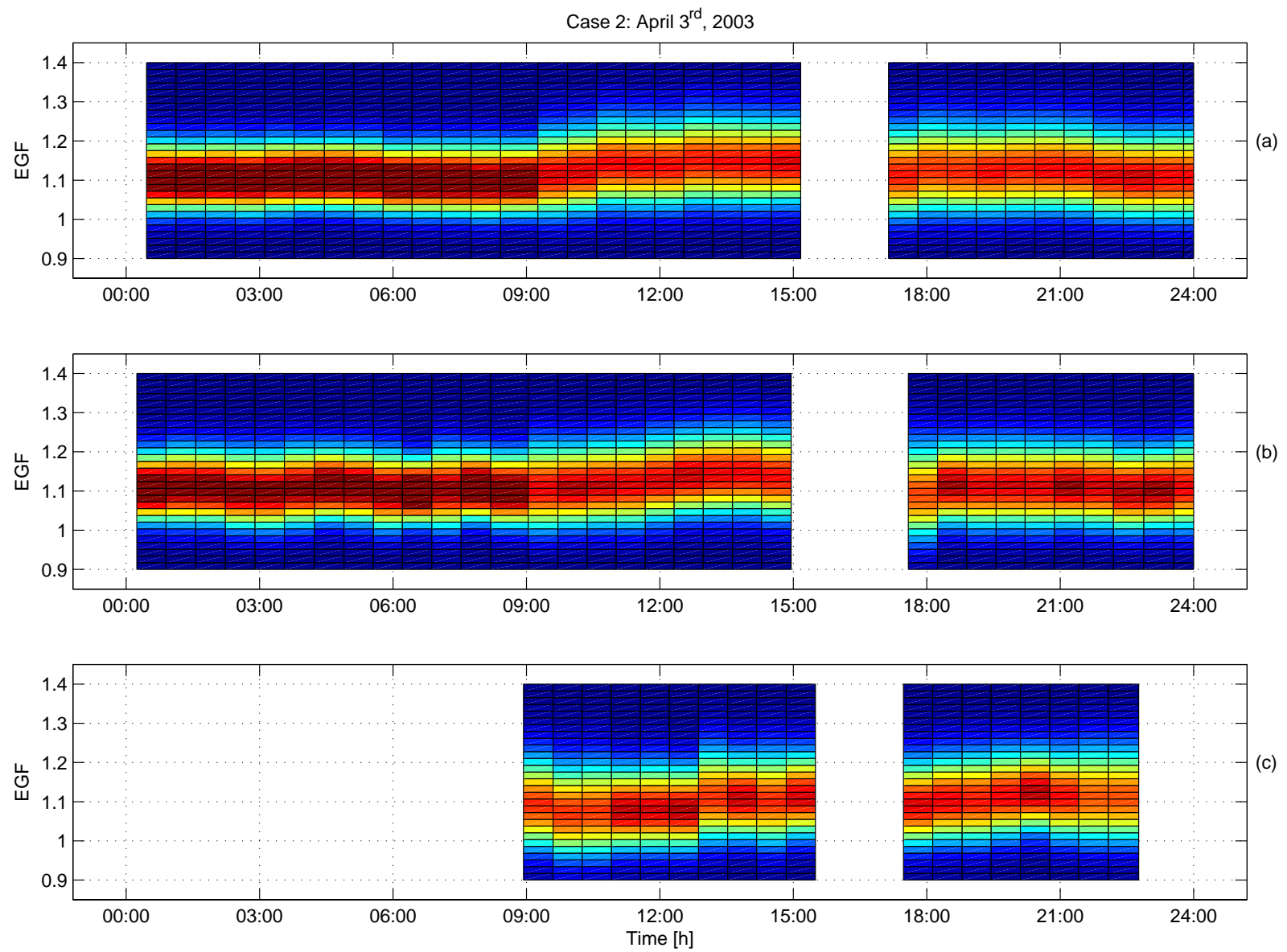

Fig. 5. Observed growth factors in ethanol vapour during 3 April 2003 (Case 2) in Hyytiälä as a contour plot for $50 \mathrm{~nm}$ (a), $20 \mathrm{~nm}$ (b) and $10 \mathrm{~nm}$ (c) particles. Average ethanol uptake is lower than during Case 1. The diurnal cycle, however, is similar.

content, since laboratory experiments have shown that $10 \mathrm{~nm}$ ammonium bisulphate and ammonium sulphate particles do not grow in ethanol vapour at ethanol saturation ratio of $86 \%$ (Vaattovaara et al., 2004).

One distict feature for the nucleation mode particles was that their water uptake had a similar minimum prior to the nucleation event as in the clean case (Case 1). The background particles, on the other hand, did not have a corresponding minimum. This indicates tentatively that compounds with very similar hygroscopic properties participated in the formation of atmospheric particles in both Case 1 and Case 2.

\subsubsection{Case 3, 7 April 2003}

The trajectory analysis showed that the air mass during 7 April 2003 came from the Arctic Ocean passing the Kola Peninsula industrial areas on their way to Hyytiälä (Fig. 1). This region is the main source area of gaseous sulphur pollution and primary particulate matter in the Arctic (Kashulina and Reimann, 2001). Also in Eastern Lapland, Finland, increased sulphur dioxide, nitrogen oxide and aerosol number concentrations have been ascribed to air masses passing over
Kola region by Ruuskanen et al. (2003). Furthermore, the signals from the emissions of Kola region industry has been detected as far as Alaska (Polissar et al., 1999).

Prior to nucleation event the particle size distribution was bimodal, typical for marine aerosol (Covert et al., 1992). The total concentration was, on average, 2000 particles $\mathrm{cm}^{-3}$ (Fig. 6). During the transport from Kola Peninsula, sulphur dioxide released into the air was oxidised to sulphuric acid. It condensed onto Aitken and accumulation mode particles on the way to the measurement site, converting the particles into more hygroscopic ones. The average hygroscopic growth factor of $50 \mathrm{~nm}$ particles during the night was 1.45 , being indicative of a large volume fraction of e.g. ammonium sulphate or compounds with similar hygroscopic properties. Consistent with the large ammonium sulfate fraction, the ethanol growth factor was rather low with a mean value below 1.1 for most of the time (pure ammonium sulfate particles do not grow in ethanol vapour). However, it appears that the mean EGF fluctuated more than in the other two cases during the night.

Although the air mass had traversed through a major $\mathrm{SO}_{2}$ source area, the concentration of gaseous sulphur dioxide 

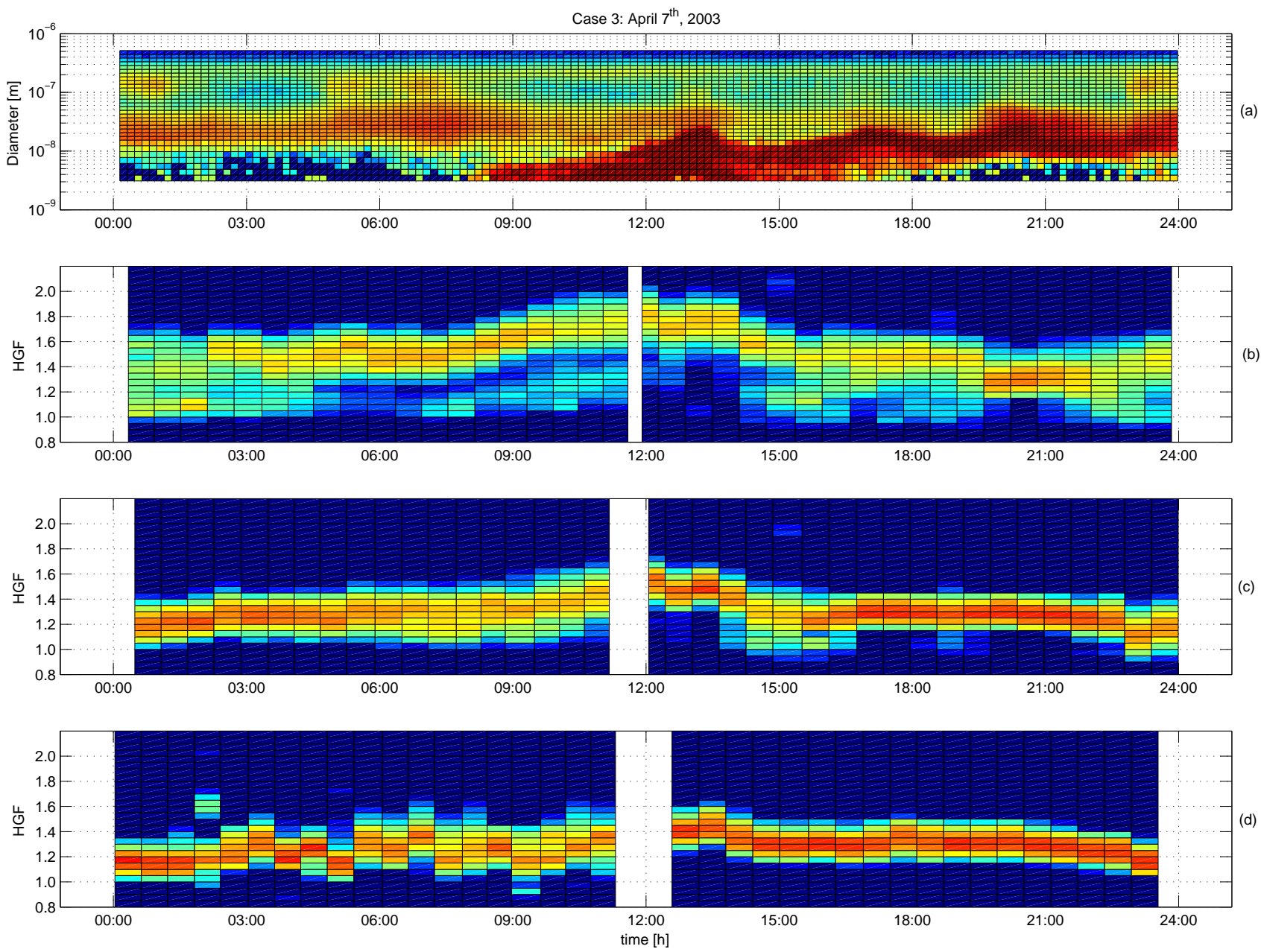

Fig. 6. Aerosol number size distribution during 7 April 2003 (Case 3) in Hyytiälä as a contour plot (a). Nucleation burst occured at 8 (LT). Prior to the nucleation burst, the hygroscopicity of $50 \mathrm{~nm}$ particles (b) was higher than in the Cases 1 and 2 . These particles accumulated sulphuric acid as they traversed with sulfur dioxide laden Arctic air to the measurement site. The water uptake increased further and reached a maximum at noon (LT), when it was comparable to values of pure ammonium sulphate aerosol. During the afternoon hours hygroscopicity decreased to similar values as in Case 2. The observed water uptake for $10 \mathrm{~nm}$ particles (d) is analogous with the Cases 1 and 2.

was similar to that in the Case 1 , in which the air had not been in contact with any major anthropogenic emission sources. The transport time from Kola Peninsula to Hyytiälä was approximately $30 \mathrm{~h}$ (Fig. 1). According to Boy et al. (2004), measured sulphuric acid concentrations were approximately by a factor of three higher during this day than during the Case 1. Furthermore, based on the measurements with the University of Manchester aerosol mass spectrometer, the aerosol composition was dominated by sulphate compounds during this day. This contrasts to the Case 2, when the particles included significant fractions of both sulphate and organics (J. Allen, personal communication, 2003).

Nucleation mode particles appeared at 08:00 (Fig. 6). The hygroscopicity of the background aerosol started to increase at 05:00-06:00 and the maximum was reached at noon when the hygroscopic growth factors corresponded to an aerosol consisting of pure ammonium sulphate (Hämeri et al., 2000). However, the EGF also increased after the onset of the nucleation, reaching 1.17 at around 15:00 (LT)(Fig. 7). This rules out pure ammonium sulphate particles, a more likely composition being a mixture of more acidic sulphate and/or condensed organics. Subsequently, as both growth factors decreased, the HGF remained higher than in the other cases whereas the EGF had rather similar values.

The hygroscopicity of the nucleation mode particles was similar to that of background particles but the noon maximum was not as pronounced. The plausible reason for this is that the nucleation mode particles had been formed more locally and had not been in the polluted air mass long enough to accumulate sulphuric acid on the way to the site. Also, Kelvin effect of the small particles limits the growth factor to some extent. By midnight the water uptake of 

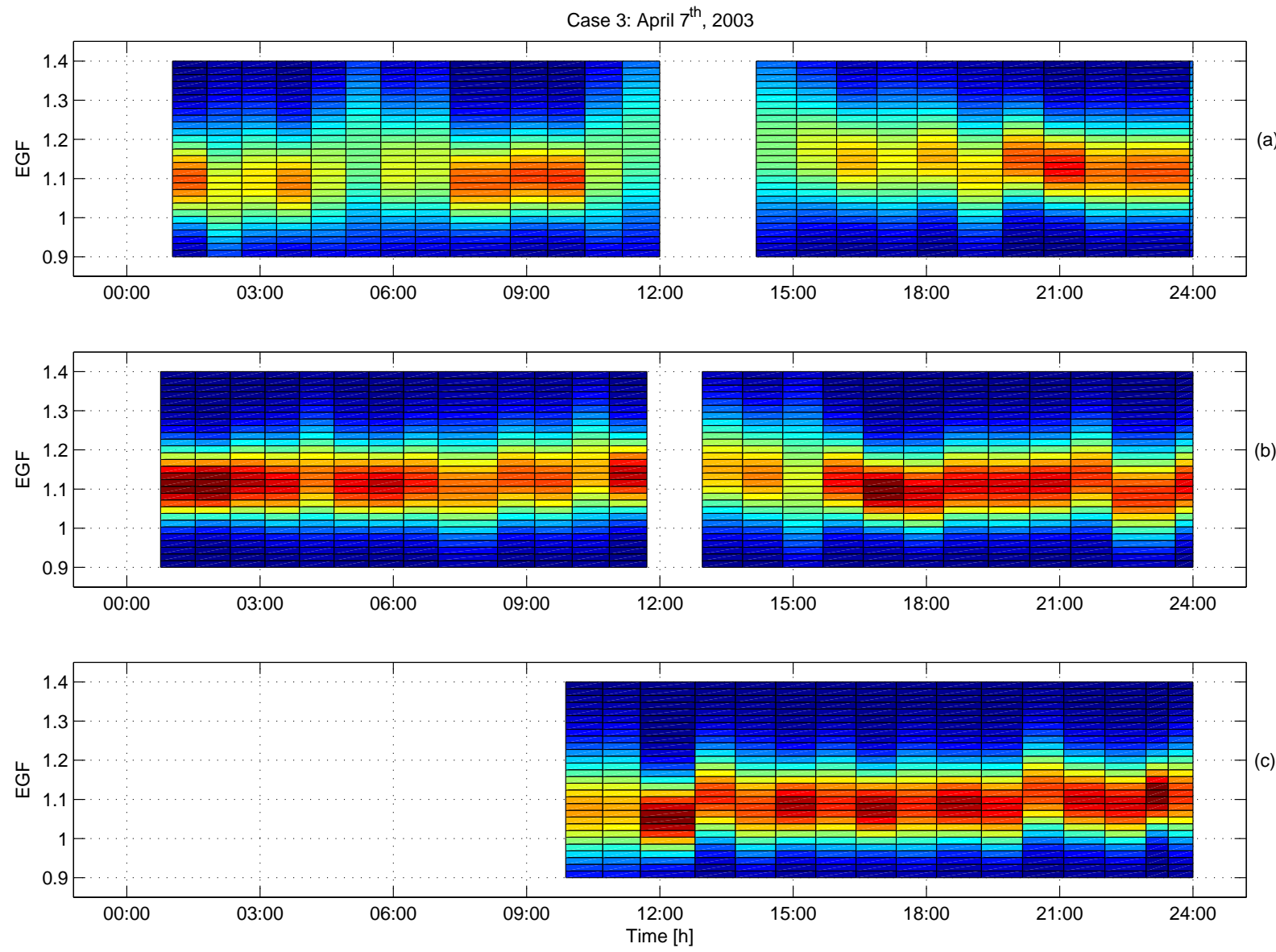

Fig. 7. Observed growth factors in ethanol vapour during 7 April 2003 (Case 3) in Hyytiälä as a contour plot for $50 \mathrm{~nm}$ (a), $20 \mathrm{~nm}$ (b) and $10 \mathrm{~nm}$ (c) particles.

ultrafine particles resembled that in the other cases. The ethanol growth factors of the $10 \mathrm{~nm}$ particles where somewhat lower than in the other cases, with values close to 1.08 during the nucleation event. Thus, compared with Case 1 and 2, the HGF was higher and the EGF lower during nucleation, which indicates a larger sulphate content of $10 \mathrm{~nm}$ particles in Case 3. Although the gas-phase sulphuric acid concentration was somewhat higher in Case 2 (3 April) than Case 3 (7 April), the nucleation mode growth was clearly more rapid during Case 2, indicating more condensation of organics relative to sulphuric acid. These differences in the water and ethanol uptake of $10 \mathrm{~nm}$ particles are, however, small compared to the differences in the $50 \mathrm{~nm}$ growth factors.

\section{Discussion and Conclusions}

The influence of air mass history, especially with regard of an exposure to anthropogenic sulphur pollution, on the observed hygroscopic properties of ultrafine Aitken and nucleation mode particles was investigated. In addition, since the complementary TDMA systems were used, a tentative indication of particle composition based on their measured water and ethanol uptakes, was available. Based on carefully selected case studies, the following picture emerged:

When originally relatively clean Arctic air traversed over major industrial areas, in this case Kola Peninsula, it captured anthropogenic pollutants such as sulphur dioxide. During the subsequent air mass transport, this $\mathrm{SO}_{2}$ was gradually oxidised to gaseous sulphuric acid which then condensed onto the aerosol particles residing in the air mass. This kind of an aging process enhanced the water affinity of originally less hygroscopic Aitken mode particles making them eventually better cloud condensation nuclei. When the transport time from major sulphur sources was shorter, as it was the case for air masses passing St Petersburg and Estonian industrial areas, there was less time for the particles to accumulate sulphuric acid. Accompanied with possibly larger soot content in the aerosol phase, this lead to lower water affinity. Finally, when clean Arctic air had no contact with any major sulphur sources, originally less hygroscopic particles remained as such during further transportation. These particles were likely to have a significant organic fraction which, on average, is substantially less hygroscopic than sulphate and other common inorganic salt present in atmospheric particulate matter. 
The hygroscopicity of nucleation mode particles was approximately the same in all the cases, being indicative of a relatively similar chemical composition despite the differences in the air mass transport routes. However, a careful examination of hygroscopic and ethanol growth factors revealed some differences: in particular, the sulphate-toorganics ratio of the nucleation mode particles appeared to be larger in the air mass arriving from Kola Peninsula compared with the air mass arriving from the St Petersburg area. It is likely, however, that this was caused by local conditions, i.e. concentrations of condensable organics in the air, than by differences in the air masses.

Based on their growth rates, the observed nucleation mode particles had been formed 3-8 $\mathrm{h}$ before the measurements. As a result, they had not as much time to accumulate gaseous sulphuric acid as did the larger and more aged Aitken mode particles. The nucleation mode particles are formed in the local or semi-local environment and thus their hygroscopicity, and therefore probably also the chemical composition, reflect local conditions in which the formation of new particles had occured.

Investigating the diurnal variation of the hygroscopic properties of ultrafine particles provided to be another useful way to analyse the contribution of different condensing vapours. Gaseous sulfuric acid, for example, is produced almost solely via the oxidation sulphur dioxide by $\mathrm{OH}$ radicals. Thus, sulphuric acid has a strong diurnal cycle with a maximum at noon. Condensing organic vapours are produced not only via $\mathrm{OH}$ radical oxidation but also via ozone and nitrate radical oxidation. Condensable organic vapours are produced therefore more steadily and even during the night-time. In any case, both organic and inorganic condensable vapours are expected to influence the hygroscopic properties of ultrafine aerosol particles.

Our results, while informative, are based on a rather limited set of measurements. Longer time series of particle hygroscopicity measurements are clearly needed to confirm the observed aging of pre-existing Aitken mode particles due to anthropogenic sulphur pollution in the clean air masses, as well as the observed similarity in the water uptake of the nucleation mode particles produced via secondary pathways despite different degree of anthropogenic influence. It might also be valuable to repeat this kind of an analyses for totally different air mass transport patterns, including the advection of originally polluted air into a clean marine or continental environment.

Acknowledgements. This work was partly supported by the European Commission via the project "Quantification of Aerosol Nucleation in the European Boundary Layer" (QUEST) (EVK2CT2001-00127). Also financial support of Emil Aaltonen foundation and the Academy of Finland is greatly appreciated. This study would not be possible without the help of personnel of SMEAR II station and Hyytiälä Forestry Field Station. NOAA Air Resources Laboratory (ARL) is acknowledged for the provision of the HYSPLIT transport and dispersion model and READY website (http://www.arl.noaa.gov/ready.html) used in this publication.

Edited by: Y. Rudich

\section{References}

Aalto, P., Hämeri, K., Becker, E., Weber, R., Salm, J., Mäkelä, J. M., Hoell, C., O’Dowd, C. D., Karlsson, H., Hansson, H.C., Väkevä, M., Koponen, I. K., Buzorius, G., and Kulmala, M. Physical characterization of aerosol particles during nucleation events, Tellus, 53B, 344-358, 2001.

Boy, M., Rannik, Ü., Lehtinen, K. E. J., Tarvainen, V., Hakola, H., and Kulmala, M.: Nucleation events in the continental boundary layer: long-term statistical analyses of aerosol relevant characteristics, J. Geophys. Res., 108(D21), 4667, doi:10.1029/2003JD003838, 2003.

Boy, M., Kulmala, M., Ruuskanen, T., Pihlatie, M., Reissell, A., Aalto, P.P., Keronen, P., Dal Maso, M., Hellen, H., Hakola, H., Jansson, R., Hanke, M., and Arnold, F.: Sulphuric acid closure and contribution to nucleation mode particle growth, Atmos. Chem. Phys. Discuss., 4, 6341-6377, 2004,

SRef-ID: 1680-7375/acpd/2004-4-6341.

Buzorius, G., Rannik, Ü., Aalto, P., Dal Maso, M., Nilsson, E. D., Lehtinen, K. E. J., and Kulmala, M.: On particle formation prediction in continental boreal forest using micrometeorological parameters, J. Geophys. Res., 108(D13), 4377, doi:10.1029/2002JD002850, 2003.

Covert, D., Gras, J., Wiedensohler, A., and Stratmann, F.: Comparison of directly measured $\mathrm{CCN}$ with $\mathrm{CCN}$ modeled from the number-size distribution in the marine boundary layer during ACE 1 at Cape Grim, Tasmania, J. Geophys. Res., 103(D13), 16 597-16 608, doi:10.1029/98JD01093, 1998.

Covert, D. S., Kapustin, V. N., Quinn, P. K., and Bates, T. S.: New particle formation in the marine boundary layer, J. Geophys. Res., 97, 20 581-20 589, 1992.

Draxler, R. and Rolph, G.: HYSPLIT (HYsplit Single-Particle Lagrangian Integrated Trajectory) model, Website (http://www. arl.noaa.gov/ready/hysplit4.html), NOAA Air Resources Laboratory, Silver Spring, MD., USA, 2003.

Ghan, S., Guzman, G., and Abdul-Razzak, H.: Competition between sea salt and sulphate particles as cloud condensation nuclei, J. Atmos. Sci., 55, 3340-3347, 1998.

Hämeri, K., Väkevä, M., Hansson, H.-C., and Laaksonen, A.: Hygroscopic growth of ultrafine ammonium sulphate aerosol measured using an ultrafine tandem differential mobility analyser., J. Geophys. Res., 105(D17), doi:10.1029/2000JD900220, 22 231$22242,2000$.

Hämeri, K., Väkevä, M., Aalto, P. P., Kulmala, M., Swietlicki, E., Zhou, J., Seidl, W., Becker, E., and O’Dowd, C. D.: Hygroscopic and $\mathrm{CCN}$ properties of aerosol particles in boreal forests, Tellus, 53B, 359-379, 2001.

Houghton, J., Ding, Y., Griggs, D., and Noguer, M. (Eds.): Climate Change 2001: The Scientific Basis, Cambridge University Press, 2001.

Janson, R., Rosman, K., Karlsson, A., and Hansson, H.-C.: Biogenic emissions and gaseous precursors to forest aerosols, Tellus, 53B, 423-440, 2001. 
Joutsensaari, J., Vaattovaara, P., Vesterinen, M., Hämeri, K., and Laaksonen, A.: A novel tandem differential mobility analyzer with organic vapor treatment of aerosol particles, Atmos. Chem. Phys., 1, 51-60, 2001,

\section{SRef-ID: 1680-7324/acp/2001-1-51.}

Joutsensaari, J., Toivonen, T., Vaattovaara, P., Vesterinen, M., Vepsäläinen, J., and Laaksonen, A.: Time-resolved growth behaviour of acid aerosols in ethanol vapor with a tandem-TDMA technique, J. Aerosol Sci., 35, 851-867, 2004.

Kashulina, G. and Reimann, C.: Sulphur in the Arctic environment (1): results of a catchment-based multi-medium study, Env. Poll., 114, 3-19, 2001.

Kerminen, V. M., Virkkula, A., Hillamo, R., Wexler, A. S., and Kulmala, M.: Secondary organics and atmospheric cloud condensation nuclei production, J. Geophys. Res., 105(D7), 9255-9264, doi:10.1029/1999JD901203, 2000.

Kulmala, M.: How Particles Nucleate and Grow, Science, 302, 1000-1001, 2003.

Kulmala, M., Dal Maso, M., Mäkelä, J., Pirjola, L., Väkevä, M., Aalto, P., Miikkulainen, P., Hämeri, K., and O'Dowd, C.: On the formation, growth and composition of nucleation mode particles, Tellus, 53B, 479-490, 2001a.

Kulmala, M., Hämeri, K., Aalto, P., Mäkelä, J., Pirjola, L., Nilsson, E. D., Buzorius, G., Rannik, Ü., Dal Maso, M., Seidl, W., Hoffmann, T., Janson, R., Hansson, H.-C., Viisanen, Y., Laaksonen, A., and O'Dowd, C. D.: Overview of the international project on biogenic aerosol formation in the boreal forest (BIOFOR), Tellus B, 53, 324-343, 2001b.

Kulmala, M., Vehkamäki, H., Petäjä, T., Dal Maso, M., Lauri, A., Kerminen, V.-M., Birmili, W., and McMurry, P.: Formation and growth rates of ultrafine atmospheric particles: a review of observations, J. Aerosol Sci., 35, 143-176, 2004

Lohman, U. and Lesins, G.: Stronger constraints on the anthropogenic indirect aerosol effect, Science, 298, 1012-1015, 2002.

McMurry, P. and Stolzenburg, M. R.: On the sensitivity of particle size to relative humidity for Los Angeles aerosols, Atmos. Environ., 23, 497-507, 1989.

Nilsson, E., Rannik, Ü., Kulmala, M., Buzorius, G., and O’Dowd, C.: Effects of the continental boundary layer evolution, convection, turbulence and entrainment on aerosol formation, Tellus, 53B, 441-461, 2001a.

Nilsson, E. D., Paatero, J., and Boy, M.: Effects of air masses and synoptic weather on aerosol formation in the continental boundary layer, Tellus, 53B, 462-478 2001b.

Novakov, T. and Corrigan, C.: Cloud condensation nucleus activity of the organic component of biomass smoke particles, Geophys. Res. Lett., 23, 2141-2144, 1996.

O'Dowd, C. D., Aalto, P., Hämeri, K., Kulmala, M., and Hoffmann, T.: Atmospheric particles from organic vapours, Nature, 416, 497-498, 2002

Peng, C., Chan, M., and Chan, C.: The hygroscopic properties of dicarboxylic and multifunctional acids: measurements and UNIFAC predictions., Environ. Sci. Technol., 35, 4495-4501, 2001.

Petäjä, T., Aalto, P., and Hämeri, K.: Hygroscopicity of toluene oxidation products, Abstracts of the Sixth International Aerosol Conference (ed. Chiu-Sen Wang), 9-13 September 2002, Taipei, Taiwan, pp. 851-852, 2002.

Polissar, A., Hopke, P., Paatero, P., Kaufmann, Y., Hall, D., Bodhaine, B., Dutton, E., and Harris, J.: The aerosol at Barrow,
Alaska: long term trends and source locations, Atmos. Environ., 33, 2441-2458, 1999.

Pradeep Kumar, P., Broekhuizen, K., and Abbatt, J.: Organic acids as cloud condensation nuclei: Laboratory studies of highly soluble and insoluble species, Atmos. Chem. Phys., 3, 509-520, 2003, SRef-ID: 1680-7324/acp/2003-3-509.

Raymond, T. and Pandis, S.: Formation of cloud droplets by multicomponent organic particles, J. Geophys. Res., 108(D15), 4469, doi:10.1029/2003JD003503, 2003.

Roberts, G., Artaxo, P., Zhou, J., Swietlicki, E., and Andreae, M.: Sensitivity of CCN spectra on chemical and physical properties of aerosol: A case study from the Amazon Basin, J. Geophys. Res., 107(D20), 8070, doi:10.1029/2001JD000583, 2002.

Rolph, G.: Real-time Environmental Applications and Display sYstem (READY), Website (http://www.arl.noaa.gov/ready/, NOAA Air Resources Laboratory, Silver Spring, MD., USA, 2003.

Ruuskanen, T., Reissell, A., Keronen, P., Aalto, P., Laakso, L., Grönholm, T., Hari, P., and Kulmala, M.: Atmospheric trace gas and aerosol particle concentration measurements in Eastern Lapland, Finland 1992-2001, Boreal Environ. Res., 8, 335-349, 2003.

Sekiguchi, M., Nakajima, T., Suzuki, K., Kawamoto, K., Higurashi, A., Rosenfeld, D., I., S., and Mukai, S.: A study of the direct and indirect effects of aerosol using global satellite data sets of aerosol and cloud parameters, J. Geophys. Res., 108(D22), 4699, doi:10.1029/2002JD003359, 2003.

Smith, J., Moore, K., McMurry, P., and Eisele, F.: Atmospheric measurements of sub-20 nm diameter particle chemical composition by Thermal Desorption Chemical Ionization Mass Spectrometry, Aerosol Sci. Technol., 38, 100-111, 2004.

Snider, J., Guibert, S., Brenguier, J.-L., and Putaud, J.-P.: Aerosol activation in marine stratocumulus clouds: 2 . Köhler and parcel theory closure studies, J. Geophys. Res., 108(D15), 8629, doi:10.1029/2002JD002692, 2003.

Stolzenburg, M. R.: An ultrafine aerosol size distribution measuring system, Ph.D. Thesis, University of Minnesota, 1988.

Vaattovaara P., Räsänen, M., Kühn, T., and Laaksonen, A.: A novel method for determining presence of carbonaceous fraction in nucleation mode particles, Abstracts of 8th international conference on carbonaceous particles in the Atmosphere, 14.-16.9, 2004, Vienna, Austria.

Vesala, T., Haataja, J., Aalto, P., Altimir, N., Buzorius, G., Garam, E., Hämeri, K., Ilvesniemi, H., Jokinen, V., Keronen, P., Lahti, T., Markkanen, T., Mäkelä, J., Nikinmaa, E., Palmroth, S., Palva, L., Pohja, T., Pumpanen, J., Rannik, Ü., Siivola, E., Ylitalo, H., Hari, P. and Kulmala, M.: Long-term field measurements of atmosphere-surface interactions in boreal forest combining forest ecology, micrometeorology, aerosol physics and atmospheric chemistry, Trends in Heat, Mass \& Momentum Transfer, 4, 17 35, 1998

Virkkula, A., Van Dingenen, R., Raes, F., and Hjort, J.: Hygroscopic properties of aerosol formed by oxidation of limonene, alpha-pinene, and beta-pinene., J. Geophys. Res., 104(D3), 3569-3579, doi:10.1029/1998JD100017, 1999.

Winklmayr, W., Reischl, G., Lindner, A., and Berner, A.: A new electromobility spectrometer for the measurement of aerosol size distributions in the size range from 1 to $1000 \mathrm{~nm}$, J. Aerosol Sci., 22, 289-296, 1991 